NBER WORKING PAPER SERIES

\title{
INTERNATIONAL RESERVES: PRECAUTIONARY VERSUS MERCANTILIST VIEWS, THEORY AND EVIDENCE
}

\author{
Joshua Aizenman \\ Jaewoo Lee \\ Working Paper 11366 \\ http://www.nber.org/papers/w11366 \\ NATIONAL BUREAU OF ECONOMIC RESEARCH \\ 1050 Massachusetts Avenue \\ Cambridge, MA 02138 \\ May 2005
}

We thank Hali Edison for sharing the data, and Aleksandra Markovic for research assistance in the earlier phase of he project. The views expressed in this paper are those of the authors and do not necessarily represent those of the IMF or IMF policy. The views expressed herein are those of the author(s) and do not necessarily reflect the views of the National Bureau of Economic Research.

(C2005 by Joshua Aizenman and Jaewoo Lee. All rights reserved. Short sections of text, not to exceed two paragraphs, may be quoted without explicit permission provided that full credit, including $\odot$ notice, is given to the source. 
International Reserves: Precautionary versus Mercantilist Views, Theory and Evidence Joshua Aizenman and Jaewoo Lee

NBER Working Paper No. 11366

May 2005, Revised February 2006

JEL No. F15, F31, F43

\begin{abstract}
This paper tests the importance of precautionary and mercantilist motives in accounting for the hoarding of international reserves by developing countries, and provides a model that quantifies the welfare gains from optimal management of international reserves. While the variables associated with the mercantilist motive are statistically significant, their economic importance in accounting for reserve hoarding is close to zero and is dwarfed by other variables. Overall, the empirical results are in line with the precautionary demand. The effects of financial crises have been localized, increasing reserve hoarding in the aftermath of crises mostly in countries located in the affected region, but not in other regions. We also investigate the micro foundation of precautionary demand, extending Diamond and Dybvig (1983)'s model to an open, emerging market economy where banks finance long-term projects with short-term deposits. We identify circumstances that lead to large precautionary demand for international reserves, providing self-insurance against the adverse output effects of sudden stop and capital flight shocks. This would be the case if premature liquidation of long-term projects is costly, and the economy is de-facto integrated with the global financial system, hence sudden stops and capital flight may reduce deposits sharply. We show that the welfare gain from the optimal management of international reserves is of a first-order magnitude, reducing the welfare cost of liquidity shocks from a first-order to a second-order magnitude.
\end{abstract}

Joshua Aizenman

Department of Economics ; E2

1156 High St.

University of California

Santa Cruz, CA 95064

and NBER

jaizen@ucsc.edu
Jaewoo Lee

Research Department

International Monetary Fund

Washington, DC 20431

jlee3@imf.org 


\section{Introduction and summary}

This paper has two goals: quantifying the relative importance of alternative views explaining international reserves accumulation, and modeling precautionary demand for international reserves, viewing it as self-insurance against costly output contractions induced by sudden stops and capital flight. This model is used to provide welfare evaluation of the costs and benefits of hoarding reserves, and the optimal size of precautionary demand.

The 1997-8 crisis in East Asia led to profound changes in the demand for international reserves, increasing over time the hoarding. Several salient features of the 1997-8 crisis may provide clues to the changing attitude towards international reserves. First, the magnitude and speed of the reversal of capital flows throughout the 1997-8 crisis surprised most observers. While the 1994 Tequila crisis induced the market to expect similar crises in Latin America, most viewed East Asian countries as being less vulnerable to the perils associated with "hot money."1 This presumption followed from the prevalent pre-1997 view -- East Asian countries were more open to international trade, had sounder overall fiscal policies, and had stronger growth performance than Latin American countries. In retrospect, the crisis exposed hidden vulnerabilities of East Asian countries, forcing the market to update the probability of sudden stops affecting all countries. The crisis also led to sharp output and investment contractions, credit crunches, and —in several countries — to full-blown banking crises. ${ }^{2}$ Finally, most affected countries went through tough adjustments, reversing the output contraction and resuming growth within several years. While a few countries flirted with capital controls, within two to three years most countries retained or increased their financial integration.

The above observations suggest that hoarding international reserves can be viewed as a precautionary adjustment, reflecting the desire for self-insurance against exposure to future sudden stops. This view, however, faces a well-known contender in a modern incarnation of mercantilism: international reserves accumulations triggered by concerns about export competitiveness. This explanation has been advanced by Dooley, Folkerts-Landau and Garber (2003), especially in the context of China. They interpret reserves accumulation as a by-product

\footnotetext{
${ }^{1}$ See Calvo (1998), Calvo and Mendoza (2000) and Edwards (2004) for further discussion on sudden stops of short-term capital flows.

${ }^{2}$ See Kaminsky and Reinhart (1999) and Hutchison and Noy (2002) for further discussion on the output costs associated with sudden stops.
} 
of promoting exports, which is needed to create better jobs, thereby absorbing abundant labor in traditional sectors, mostly in agriculture. Under this strategy, reserves accumulation may facilitate export growth by preventing or slowing appreciation. Some view the modern mercantilist approach as a valid interpretation for most East Asian countries, arguing that they follow similar development strategies. This interpretation is intellectually intriguing, especially in the broader context of the "Revived Bretton Woods system," yet it remains debatable. Some have pointed out that high export growth is not the new kid on the block -- it is the story of EastAsia during the last fifty years. Yet, the large increase in hoarding reserves has happened mostly after 1997. This issue is of more than academic importance: the precautionary approach links reserves accumulation directly to exposure to sudden stops, capital flight and volatility, whereas the mercantilist approach views reserves accumulation as a residual of an industrial policy, a policy that may impose negative externalities on other trading partners.

Our empirical test augments previous econometric specifications of international reserves by adding two sets of variables. The first set deals with factors associated with mercantilist motives: lagged export growth and deviations from predicted purchasing power parity (PPP). The second set of variables attempts to capture precautionary adjustment in the aftermath of unanticipated sudden-stop crises, using dummy variables. Specifically, two crucial events were the 1994 Mexican crisis and the 1997 East Asian crisis. Both happened at times of greater financial integration, promoted by relaxing capital controls. Our results provide only a limited support for the mercantilist approach. While the variables associated with the mercantilist motive are statistically significant, their economic importance in accounting for reserves hoarding is close to zero and is dwarfed by other variables. Specifically, trade openness, measured by the GDP share of imports, and crises variables are playing a much more important role in accounting for reserves accumulation than lagged export growth and PPP deviations. This result applies to all countries, including China. Indeed, inspecting the magnitude of country-specific dummies reveals that China is not an outlier in the level of reserves. We also find strong localized effects of crises: while the 1994 Mexican crises increased reserves in Mexico, it did not affect reserves in East Asia. Similarly, the 1997 crisis strongly increased the hoarding of reserves in East Asia, but not in Latin America. Across all specifications, a more liberal capital account regime is found to increase the amount of international reserves. This by itself constitutes evidence in favor of the precautionary view, for capital account liberalization will boost the precautionary 
motive more than the mercantilist motive. Moreover, the inclusion of capital control variables weaken the statistical significance of deviations from PPP, one of the two mercantilist variables, while having little effect on the statistical significance of crisis variables.

Overall, the empirical results of Section 2 are in line with the precautionary demand. Yet, the precautionary demand approach has not been endorsed uniformly. Skeptical views point out that the sheer magnitude of reserves accumulated by East Asian countries seems excessive once attention is paid to the opportunity costs of reserves. In order to deal with these concerns, we provide in Section 3 a simple model characterizing and quantifying the welfare gains attributed to hoarding reserves in the presence of exposure to external liquidity shocks. The model extends the literature dealing with the demand for bank reserves in the closed economy to the important, yet less studied open-economy context. ${ }^{3}$ Specifically, we consider a country exposed to international liquidity shocks, which in turn can cause liquidation and consolidation of investment. A key postulate of the analysis is that, short of having a credible international lender of last resort, hoarding international reserves is among the few options allowing developing countries to reduce the output costs of sudden stops. While hoarding international reserves has its opportunity cost, we identify circumstances where the welfare gain from hoarding reserves is of a first-order magnitude, leading to potentially large precautionary demand for reserves.

The earlier literature focused on using international reserves as part of the management of an adjustable-peg or managed-floating exchange rate regime [Frenkel (1983), Edwards (1983); see Flood and Marion (2001) for a literature review]. To our knowledge, our paper is the first econometric attempt to evaluate the relevance of the mercantilist approach in the aftermath of the 1997 crisis [see Aizenman and Marion (2003); Edison (2003); and Aizenman, Lee and Rhee (2004) for earlier empirical analysis of related issues]. The model advanced in Section 3 contributes to the growing literature linking international reserves with sovereign risk and limited access to the global capital market. Past literature has considered precautionary motives for hoarding international reserves needed to stabilize fiscal expenditure in countries with limited

\footnotetext{
${ }^{3}$ See Bryant (1980); Diamond and Dybvig (1983) and Prisman, Solvin and Sushka (1986) for earlier literature dealing with optimal reserves (liquidity) policy in a closed economy.
} 
taxing capacity and sovereign risk [see Aizenman and Marion (2004)]. ${ }^{4}$ Insurance perspectives of international reserves applying the option pricing theory are provided in Lee (2004). The model in this paper is more closely related to the literature viewing international reserves as output stabilizers [see Ben-Bassat and Gottlieb (1992), Aizenman, Lee and Rhee (2004) and García and Soto (2004)]. Our paper adds to this literature by providing an explicit model of financial intermediation and adjustment subject to liquidity shocks, where hoarding international reserves emerges as part of the optimal financial intermediation.

As our focus is on developing countries, we assume that all financial intermediation is done by banks, relying on debt contracts. Specifically, we consider the case where investment in a long-term project should be undertaken prior to the realization of liquidity shocks. Hence, shocks may force costly liquidation of earlier investments, thereby reducing output. We solve the optimal demand for deposits and international reserves by a bank that finances investment in long-term projects. The bank's financing is done using callable foreign deposits, which exposes the bank to liquidity risk. Macro liquidity shocks stemming from sudden stops and capital flights cannot be diversified away. ${ }^{5}$ In these circumstances, hoarding reserves saves liquidation costs, potentially leading to large welfare gains, and these gains hold even if all agents are risk neutral. In this framework, deposits and reserves are complements - higher volatility of liquidity shocks will increase both the demand for reserves and deposits. The optimal hoarding of reserves to accommodate more volatile liquidity shocks reduces the output cost of these shocks from firstorder to second-order magnitude.

\section{International Reserves: Evidence}

Our empirical analysis adds several new controls to past regressions. The mercantilist view focuses on hoarding international reserves in order to prevent or mitigate appreciation, with

\footnotetext{
${ }^{4}$ The precautionary demand modeled in this paper supplements the precautionary demand stemming from fiscal considerations. For example, one may argue that the prospect of unification of North and South Korea [or a conflict in the worst-case scenario] may explain part of the hoarding of international reserves by Korea. Yet, we may qualify this argument by noting that one expects the US and the OECD countries to provide the credit needed to finance the unification (or the conflict). This argument, however, does not extend to the case of a sudden stop and capital flight. As the 1997 crisis illustrated, external finance at times of sudden stops is not forthcoming without stringent conditions and is frequently limited due to moral hazard considerations.

${ }^{5}$ The recent history of Argentina provided a vivid illustration of the limited ability to diversify away liquidity shocks. In the mid-1990s Argentina negotiated contingent commercial credit lines in an attempt to provide external insurance against liquidity shocks. These lines, however, dried up as Argentina approached the crisis.
} 
the ultimate goal of increasing export growth. Hence, we expect that reserves hoarding provoked by mercantilist concerns should be associated with higher export growth rate, and with deprecated real exchange rate relative to the fundamental PPP real exchange rate. In order to control for export growth, we constructed a three-year moving average of the growth rate of real exports (denoted MVGX), lagged two years in the regression. ${ }^{6}$ Our "fundamental” PPP real exchange rate is defined as the fitted value from the the regression of national price levels on the per-worker income relative to the U.S. for nearly 150 countries, motivated by the classic Penn effect (see the regression reported in Table 1A). ${ }^{7}$ The deviations from the "fundamental” PPP value, denoted by PLDE, are measured by the residuals of this regression, and are found to bring about an appreciation in the nominal effective exchange rates in the subsequent year for our sample countries (lower panel of Table 1A). If a country whose price level is higher than the level implied by its relative income tends to accumulate international reserves in an effort to slow the pace of appreciation in its currency, the coefficient on PLDE will be positive in the regression of international reserves on usual determinants including PLDE.

The second set of controls attempts to capture the effects of two important crises: the 1994 Mexican, and the 1997-8 East-Asian crises. This is done by applying a dummy variable to each crisis [CRMEXEM: 1 since 1995, 0 before; CRASIAEM: 1 since 1998, 0 before]. In one of the regressions we apply continental dummies for each crisis (see data appendix for definitions). In addition, we control for log of population (LPOP); log of percent import share (LIMY); exchange rate volatility (VOL_XC); and log of per-capita income (LYPC) in one set of regressions. Various permutations of these regressions are summarized in Tables 1 and 2, covering 1980-2000. Figures 1 and 2 summarize the contribution of the various variables in regression III to the dependent variable in the 1990s, for six countries [Argentina, Brazil, Chile, China, Korea, and Mexico].

The dependent variable in Table 1 is the reserves/broad money ratio. Higher lagged export growth and national price level above the fundamental level predicted by relative GDP per capita regression are associated with higher reserves/broad money, and this effect is statistically significant. Similarly, the Mexican and the East-Asian crises increased the demand for reserves, and this effect is statistically significant.

\footnotetext{
${ }^{6}$ We used lags to deal with possible endogeneity issues.

${ }^{7}$ See Kravis (1984) for a classic reference on PPP, and Samuelson (1994) for the apt expression "Penn effect."
} 
Figure 1 allows one to inspect the economic significance of each variable in accounting for the observed reserves ratios for six countries. The solid line denotes the dependent variable, the ratio of reserves to broad money. All other lines, which denote the contribution of each variable to the reserves/broady money ratio, are calculated by multiplying each variable and the associated coefficient from regression. The variables presented separately in the figure are the import share (LIMY in the table), post crisis effect (the combined effect of CRMEXEM and CRASIAEM), export growth (MVGX), and the relative PPP (PLDE). All other variables - the population, exchange rate volatility and constant term-are combined into one series (others), because their effects show little variation over time.

Figure 1 indicates a similar pattern for all the countries: trade openness is frequently the most important consideration. The variables associated with mercantilist concerns are practically flat, and their economic significance in accounting for the observed hoarding of international reserves is close to zero. The crisis variables play an important role in all the six countries, including China. The regional crisis dummy variables used in regression IV reveal an intriguing pattern -- the Mexican crisis is associated with higher demand for reserves in Latin America, but not in Asia. Similarly, the 1997 East-Asian crisis is associated with higher hoarding of reserves in Asia, but lower reserves in Latin America [a drop of 5 percentage points in the aftermath of the 1997 crisis]. Regression V reveals that the size of the variables associated with mercantile concerns is not impacted by crises, hence it rejects the possibility that crises magnified mercantilist concerns.

The dependent variable in Table 2 is the reserves/GDP ratio, and per-capita income is excluded from the regression. Overall, the results are very similar to the one associated with reserves/broad money. The main changes are that the impact of crises is sharper on reserves/GDP than on reserves/broad money. Figure 2 summarizes the economic significance of each variable in accounting for the observed reserves ratios for six countries. It reveals similar patterns to Figure 1. Note that in the case of China, reserves/GDP ratio increased mostly after 1994, from 0.10 in 1994 to about 0.16 in 1998-2000. The most important variable “explaining” this increase in the reserves/GDP ratio is the crises dummies (about 0.05 out of the increase of 0.06). All the other variables, including the two mercantilist variables, provide practically zero 
explanation to reserves/GDP ratio, in terms of the level or the change. ${ }^{8}$ Openness, measured by the import share, did not play a prominent role in this increase of the reserves/GDP ratio, but is an important explanator of the level of reserves. The import share accounts for 0.11 out of 0.16 , the 1998-2000 average of the reserves/GDP ratio. The size of population also makes a very large contribution to the level of reserves, but varies little over time and thus is combined with other variables and the constant term in the figure.

Nor is the mercantilist effect an important factor in accounting for differences in the level of reserves across different countries. Figure 3 compares the relative importance of several regressors by plotting the effect of an increase in the value of each variable by one standard deviation. In this figure, the standard deviation of each variable is calculated across countries using the data in 2000, but similar results arise when the standard deviations are calculated for the pooled data over the whole sample period. Among the two mercantilist variables, the deviation of the PPP exchange rate plays a more important role in explaining the reserves/GDP ratio, but its effect pales by the effects of crisis or openness. Population plays quantitatively the most important role in explaining cross-country differences in the level of reserves, but is not presented and compared with other variables in Figure 3. Population moves very little over time unlike other economic variables, making it conceptually more comparable to country specific effects rather than the effects of other economic variables.

Figure 4 plots the distribution of the country specific effects, identifying the names of the six countries evaluated in Figures 1-2 and several others with country specific effects that differ from the average of all country specific effects by nearly or more than two standard deviations. Note that China's country specific effect is negative, and is inconsistent with the notion that China's large reserves make it an outlier in the context of the cross country panel comparison, 1980-2000. For both China and India, the clear negative values of country specific effects reflect the large sizes of their population. In regressions that excluded the population variable from the regressors, the country specific effects on China and India were closer to zero than in the regressions with population. With or without considering the effect of population, China is not an outlier with a large positive country-specific effect. One such country is Singapore, a country well known for its traditionally very high level of international reserves that often exceeded 80

\footnotetext{
${ }^{8}$ See Prasad and Wei (2005) for recent skeptical perspectives about the mercantilist interpretation of Chinese reserves accumulation.
} 
percent of its GDP during the sample period, and its country-specific effect is close to three standard deviations. Two countries with smaller but still large country-specific effect—about two standard deviations away from the average-are Cyprus and Hong Kong SAR, in the latter of which the currency board system necessitates a high level of reserves.

In terms of the horse race between the mercantilist and precautionary views of international reserves, our results suggest that the precautionary motive played a more visible role in the accumulation of reserves than the mercantilist motive. At minimum, we could identify the likely effect of precautionary motive more easily and strongly than the likely effect of mercantilist motive.

This summary interpretation remains intact when we control for changes in capital account regimes. Tables 3 and 4 repeat the regression of Tables 1 and 2, respectively, but including the variable that captures the degree of capital account liberalization (K liberalization). This variable, constructed by Edwards (2005), measures the degree of capital account liberalization in finer grids than most existing measures. Across all specifications, a more liberal capital account regime is found to increase the amount of international reserves. This by itself constitutes evidence in favor of the precautionary view, for capital account liberalization will boost the precautionary motive more than the mercantilist motive. Moreover, the inclusion of capital control variables weaken the statistical significance of PLDE, one of the two mercantilist variables, while having little effect on the statistical significance of crisis variables.

\section{The model}

We construct a minimal model to explain the self insurance offered by international reserves in mitigating the output effects of liquidity shocks. The structure of the model is akin to Diamond and Dybvig (1983) -- investment in a long term project should be undertaken prior to the realization of liquidity shocks. Hence, the liquidity shock may force costly liquidation of the earlier investment, reducing second period output. As our focus is on developing countries, we assume that all financial intermediation is done by banks, relying on a debt contract. We simplify further by assuming that there is no separation between the bank and the entrepreneur the entrepreneur is the bank owner, using it to finance the investment. The time line is summarized in Figure 5. At the beginning of period 1, risk neutral agents deposit D in banks, which in turn use $\mathrm{D}$ to finance long term investment, $K_{1}$, and hoarding reserves, R. A liquidity 
shock, with the aggregate value of $\mathrm{Z}$ for the borrowing economy, materializes at the end of period 1, after the commitment of capital. A liquidity shock exceeding reserves induces a premature liquidation of $\mathrm{Z}$ - R. Output increases with the capital invested at the beginning of period one, $K_{1}$, and declines with liquidation at a rate that depends on the adjustment cost, $\theta$. Assuming a Cobb-Douglas production function, the second period output is

$$
Y_{2}=\left[K_{1}-(1+\theta) M A X\{Z-R, 0\}\right]^{\alpha} \text {; where } 0 \leq \theta<1 \text {, and } \alpha<1 \text {. }
$$

Recalling that $K_{1}=D-R$, the net capital after liquidation is:

$$
\text { (2) } \quad K_{2}= \begin{cases}D-R-(1+\theta)(Z-R)=D-Z-\theta(Z-R) & \text { if } Z>R \\ D-R & \text { if } Z \leq R\end{cases}
$$

It is convenient to normalize the liquidity shock by the level of deposits, denoting the normalized shock by z:

(3) $\quad Z=z D ; \quad 0 \leq z<\tau \leq 1$, and density $f(z)$.

Depositors are entitled to a real return of $r_{D}$ on the loan that remains deposited for the duration of investment. $^{9}$ Assuming agents' subjective discount rate is $\rho$, competitive intermediation implies that

$$
\int_{0}^{\tau}(1-z) f(z) d z=\frac{\left(1+r_{D}\right) \int_{0}^{\tau}(1-z) f(z) d z}{1+\rho} \Rightarrow r_{D}=\rho .
$$

\footnotetext{
${ }^{9}$ The possibility that the outcome of investment is not large enough to meet the promised rate of return is discussed later. To preview, this possibility does not affect the main conclusion of our analysis, because of the assumption of risk neutrality.
} 
Net reserves held until period 2 are assumed to yield a return of $r_{f}$. We denote the marginal liquidity shock associated with liquidation by $z^{*}, z^{*}=R / D$. The expected second period surplus [i.e., net income after paying depositors] is:

$$
\begin{array}{r}
E[\Pi]=\int_{0}^{z^{*}}(D-R)^{\alpha} f(z) d z+\int_{z^{*}}^{\tau}(D-Z-\theta[Z-R])^{\alpha} f(z) d z+ \\
\left(1+r_{f}\right) \int_{0}^{z^{*}}[R-Z] f(z) d z-(1+\rho) D \int_{0}^{\tau}(1-z) f(z) d z .
\end{array}
$$

It is the sum of the expected output, plus the income associated with reserves net of liquidation, minus the repayment to depositors who get a return of $\rho$ on the net deposit position, $D-Z$. Applying (3) and the definition of the $\mathrm{z}^{*}$, we re-write the expected surplus as

$$
\begin{aligned}
& E[\Pi]=D^{\alpha} {\left[\int_{0}^{z^{*}}\left(1-z^{*}\right)^{\alpha} f(z) d z+\int_{z^{*}}^{\tau}\left(1-z-\theta\left[z-z^{*}\right]\right)^{\alpha} f(z) d z\right]+} \\
& D\left[\left(1+r_{f}\right) \int_{0}^{z^{*}}\left(z^{*}-z\right) f(z) d z-(1+\rho) \int_{0}^{\tau}(1-z) f(z) d z\right]
\end{aligned}
$$

The FOC determining the optimal demand for international reserves is

$$
\begin{aligned}
0=D^{\alpha-1}\left[-\alpha\left(1-z^{*}\right)^{\alpha-1} \int_{0}^{z^{*}} f(z) d z+\theta \int_{z^{*}}^{\tau} \alpha\left(1-z-\theta\left[z-z^{*}\right]\right)^{\alpha-1} f(z) d z\right]+ \\
\left(1+r_{f}\right) \int_{0}^{z^{*}} f(z) d z .
\end{aligned}
$$

This condition is equivalent to:

$$
\left[M P_{K_{1}}-\left(1+r_{f}\right)\right] \cdot \operatorname{Pr}[Z<R]=\theta E\left[M P_{K} \mid Z>R\right]
$$

where $M P_{K_{1}}$ is the marginal productivity of capital, and $\operatorname{Pr}[Z<R]$ is the probability that the liquidity shock is below the level of reserves. The expected opportunity cost of holding reserves is equalized to the expected precautionary benefit of holding reserves. 
Figure 5 plots the final output (the solid line) as a function of liquidity shock, $\mathrm{z}$, drawn for a given initial investment and reserves hoarding. For liquidity shocks below z*, output is flat, independent of the realized liquidity shock. A liquidity shock above $\mathrm{z}^{*}$ requires costly downward adjustment of capital, reducing thereby final output. A marginal increase of the initial reserves position will shift the output line in two different directions. First, hoarding extra dollar reserves reduces the initial capital by one dollar, reducing output for liquidity shocks below $\mathrm{z}^{*}$; shifting the output line downward for $\mathrm{z}<\mathrm{z}^{*}$ (the downward shift equals $M P_{K_{1}}$ ). Extra dollar reserves implies, however, lower deadweight loss associated with liquidation, shifting thereby the output line to the right for $\mathrm{z}>\mathrm{z}^{*}$. The decrease in output associated with extra dollar reserves is depicted in Figure 6 by the shaded area below the old production curve, for $\mathrm{z}<\mathrm{z}^{*}$. Similarly, the increase in output associated with the extra dollar reserves correspond to the shaded area to the right of the old production curve, for $\mathrm{z}>\mathrm{z}^{*}$. The expected net gain in production from holding reserves corresponds to the difference between the two shaded areas, properly weighted by $\mathrm{f}(\mathrm{z})$, as well as the expected gross income attributed to extra dollar reserves. Optimal reserves, which satisfy equation (7), maximize the overall expected gain.

The first order condition characterizing optimal deposit can be rewritten as:

$$
\begin{aligned}
0=\alpha D^{\alpha-1}\left[\int_{0}^{z^{*}}\left(1-z^{*}\right)^{\alpha-1} f(z) d z+\int_{z^{*}}^{\tau}\left(1-z-\theta\left[z-z^{*}\right]\right)^{\alpha-1}(1-z[1+\theta]) f(z) d z\right]- \\
\left\{\left(1+r_{f}\right) \int_{0}^{z^{*}} z f(z) d z+(1+\rho) \int_{0}^{\tau}(1-z) f(z) d z\right\}
\end{aligned}
$$

We first consider the case with small shocks to gain the basic insight for the welfare gains associated with reserves. In the absence of uncertainty, the optimal level of deposits $\left(D_{0}^{*}\right)$, and the resultant surplus $\left(\Pi_{0}\right)$ are:

$$
D_{0}^{*}=\left[\frac{\alpha}{1+\rho}\right]^{1 /(1-\alpha)} ; \quad \Pi_{0}=(1+\rho) D_{0}^{*} \frac{1-\alpha}{\alpha}
$$


Suppose that the liquidity shocks are either zero or $z_{0}$, with probability half each, and $\rho=r_{f}$. If reserves are set to zero, and deposits at $D_{0}^{*}$, the expected surplus is

(9) $E[\Pi]_{\mid R=0}=\frac{\left[D_{0}^{*}\right]^{\alpha}-(1+\rho) D_{0}^{*}}{2}+\frac{\left[D_{0}^{*}\left(1-(1+\theta) z_{0}\right)\right]^{\alpha}-(1+\rho) D_{0}^{*}\left(1-z_{0}\right)}{2}$.

Applying (8’) to (9), the first order approximation of the expected surplus can be reduced to

$$
E[\Pi]_{\mid R=0} \cong \Pi_{0}-\theta \frac{z_{0}(1+\rho) D_{0}^{*}}{2}
$$

Liquidity shocks have a first order adverse effect on expected surplus. In the absence of the insurance provided by reserves, liquidation induces a deadweight loss equal to the adjustment cost, $\theta$, times the expected liquidation. This result is not affected if we allow the optimal adjustment of deposits: the envelope theorem implies that such an adjustment would have only second order effects. ${ }^{10}$

In a two states of nature case, perfect stabilization can be achieved by hoarding reserves equal to the liquidity shock: $R=z_{0} D_{0}^{*}$; adjusting deposits to $D=\left(1+z_{0}\right) D_{0}^{*}$, thereby setting the stock of capital at $K_{1}=D_{0}^{*}$. If the liquidity shock materializes, R would provide the needed liquidity, preventing costly output adjust. If the shock is nil, there would no need to use R. The assumption that $\rho=r_{f}$ implies that the cost of this insurance is zero. Consequently, ${ }^{11}$

\footnotetext{
${ }^{10}$ This follows from the observation that $\frac{d E[\Pi]_{\mid R=0}}{d z_{0}} \cong \frac{\partial E[\Pi]_{\mid R=0}}{\partial D} \frac{d D}{d z_{0}}+\frac{\partial E[\Pi]_{\mid R=0}}{\partial z_{0}}=\frac{\partial E[\Pi]_{\mid R=0}}{\partial z_{0}}$ (recall that the FOC determining deposits is $\frac{\partial E[\Pi]_{\mid R=0}}{\partial D}=0$ ).

${ }^{11}$ With more than two states of nature, $\mathrm{R}$ would be preset at the ex-ante efficient level, providing full insurance for liquidity shocks below $\mathrm{z}^{*}$, and partial insurance above. While there is no way to insure complete stabilization, one expects large welfare gain from setting $\mathrm{R}$ at the ex-ante efficient level relative to the case of $\mathrm{R}=0$.
} 
(9”) $\quad E[\Pi]_{\mid R=z_{0} D_{0}^{*}}=\Pi_{0}$

This simple example suggests that liquidity shocks have a first order welfare effects in the absence of reserves, and that hoarding reserves can reduce the cost of liquidity shocks from first to second order magnitude. We confirm this conjecture by a detailed simulation of the case where liquidity shocks follow a uniform distribution, $f(z)=1 / \lambda ; \lambda=\tau<1$. Figure 7 plots the association between volatility and the reserves/deposit ratio for the case where the level of deposit is kept at the level of equation (8'). The reserves ratio increases with the volatility. Allowing for the optimal adjustment of D according to equation (8), it follows that $\frac{d D}{d R} \mid R=0$. The increase in $\mathrm{D}$ is needed to mitigate the costly drop in output induced by reserves accumulation, and is needed to keep the planned capital at the optimal level. ${ }^{12}$ Table 5 traces the impact of higher volatility for the case where both reserves and deposits are adjusting optimally, contrasting it to the case where reserves are set to zero [the last two columns]. Specifically, the first four columns report the optimal reserves/deposit ratio, deposits, reserves and expected surplus as a function of volatility, assuming that $\mathrm{R}$ and $\mathrm{D}$ are adjusted optimally. The last two columns report D and expected surplus for case where R is zero, and only D is adjusted optimally.

\section{Discussion:}

In the absence of reserves, the volatility has first order effects on output: increasing volatility from zero to 0.6 reduces expected surplus by about $15 \%$. Hoarding the optimal level of reserves reduces the cost of volatility into a second order magnitude, about 3\%. Hence, optimal reserves have a first order welfare effect, increasing the expected surplus by about $12 \%$ relative to the case of zero reserves. Accomplishing this gain requires relatively large reserves, about half of the deposit level for the case where $\lambda=0.6$. The effect of volatility with optimal reserves hoarding is to increase both deposits and reserves, while keeping the level of planned capital $K_{1}$ almost constant.

\footnotetext{
${ }^{12}$ Recalling (2), higher $\mathrm{R}$ reduces the stock of capital in states of nature where $Z<R$ by $\Delta R$, but increases the stock of capital in states of nature where $Z>R$ by $\theta \Delta R$.
} 
Our discussion assumed so far that the limited liability constraint does not bind: that is,

$$
D^{\alpha}\left(1-z-\theta\left[z-z^{*}\right]\right)^{\alpha}>D(1+\rho)(1-z) \quad \text { for all } z \text {. }
$$

Indeed, it can be verified that the limited liability constraint is not binding in the simulation reported in Table 5. We now show that our main results are not dependent on these parametric assumptions. The limited liability constraint would bind if $D^{\alpha}\left(1-z-\theta\left[z-z^{*}\right]\right)^{\alpha}<D(1+\rho)(1-z)$ in some states of nature, which may hold for large enough volatility and adjustment cost. We denote the contractual interest rate on deposits in the presence of binding liability constraint by $\rho_{d}$, and by $\tilde{z}$ the threshold liquidity shock associated with zero surplus: ${ }^{13}$

$$
D^{\alpha}\left(1-\tilde{z}-\theta\left[\tilde{z}-z^{*}\right]\right)^{\alpha}=D\left(1+\rho_{d}\right)(1-\tilde{z}) .
$$

For liquidity shocks above this threshold, we assume that depositors are paid a fraction $\phi$ of the output, $0 \leq \phi \leq 1$. $^{14}$ Note that binding limited liability constraint implies that depositors are exposed to the downside risk associated with large liquidity shock. Hence, depositors would demand a high enough deposit interest rate $\rho_{d}$ to compensate for the exposure. For risk neutral depositors, the equilibrium interest rate is determined by the following brake even condition:

\footnotetext{
${ }^{13}$ Note that for $\frac{1+\theta z^{*}}{1+\theta}=z$, output is zero, and the bank would default. Hence, a sufficient condition for the limited liability constraint to bind is $\frac{1+\theta z^{*}}{1+\theta}<\lambda$. Equation (11) implies, however, that $\tilde{z}<\lambda$, and the limited liability constraint may bind even if $\frac{1+\theta z^{*}}{1+\theta}>\lambda$.

${ }^{14}$ The conventional closed-economy assumption is $\phi=1$. The case where $\phi<1$ can capture the presence of repatriation risk, where the banks pays foreign creditors only a fraction $\phi$ of output for $Z>\widetilde{Z}$, or the efficiency loss associated with debt restructuring.
} 


$$
(1+\rho) D \int_{0}^{\tau}(1-z) f(z) d z=\left(1+\rho_{d}\right) D \int_{0}^{\tilde{z}}(1-z) f(z) d z+\phi \int_{\tilde{z}}^{\tau}\left(D\left(1-z-\theta\left[z-z^{*}\right]\right)^{\alpha} f(z) d z\right.
$$

where the threshold $\tilde{z}$ is determined by (11). Consequently, the expected surplus is:

$$
\begin{aligned}
& E[\Pi]=D^{\alpha}\left[\int_{0}^{z^{*}}\left(1-z^{*}\right)^{\alpha} f(z) d z+\int_{z^{*}}^{\tilde{z}}\left(1-z-\theta\left[z-z^{*}\right]\right)^{\alpha} f(z) d z\right]-\left(1+\rho_{d}\right) D \int_{0}^{\tilde{z}}(1-z) f(z) d z+ \\
& (1-\phi) \int_{\tilde{z}}^{\tau}\left(D\left(1-z-\theta\left[z-z^{*}\right]\right)^{\alpha} f(z) d z+D\left(1+r_{f}\right) \int_{0}^{z^{*}}\left(z^{*}-z\right) f(z) d z=\right. \\
& D^{\alpha}\left[\int_{0}^{z^{*}}\left(1-z^{*}\right)^{\alpha} f(z) d z+\int_{z^{*}}^{\tau}\left(1-z-\theta\left[z-z^{*}\right]\right)^{\alpha} f(z) d z\right]+ \\
& D\left[\left(1+r_{f}\right) \int_{0}^{z^{*}}\left(z^{*}-z\right) f(z) d z-(1+\rho) \int_{0}^{\tau}(1-z) f(z) d z\right] .
\end{aligned}
$$

Note that (13) is identical to the expected surplus in the base case of the previous section, (5'). With risk neutral agents, binding limited liability constraint changes the deposit interest rate, without changing the entrepreneur's expected surplus and investment patterns. ${ }^{15}$

\section{Concluding remarks}

Our study has outlined a procedure that helps to identify the contributions of precautionary and mercantilist motives to the hoarding of international reserves. Applying it to 1980-2000, we found that variables associated with trade openness and exposure to financial crises are both statistically and economically important in explaining reserves. In contrast, variables associated with mercantilist concerns are statistically significant, but economically insignificant in accounting for the patterns of hoarding reserves. These results hold for most countries, including China. We provided a model that shows that precautionary demand is consistent with high levels of reserves. We close the paper with qualifying remarks. As is the case with all empirical studies, more accurate and updated data may modify the results. Our empirical study does not imply that the hoarding of reserves by countries is optimal or efficient. Making inferences regarding efficiency would require having a detailed model and much more information, including an assessment of the probability and output costs of sudden stops, and the

\footnotetext{
${ }^{15}$ This result holds because we assumed the absence of enforcement and monitoring costs, and that all agents are risk neutral.
} 
opportunity cost of reserves. Our study reveals, however, that existing patterns of growing trade openness and greater exposure to financial shocks by emerging markets go a long way towards accounting for the observed hoarding of international reserves. 


\section{References}

Aizenman, J. and N. P. Marion (2003). "The High Demand for International Reserves in the Far East: What's Going On?" Journal of the Japanese and International Economies, 2003, 17/3, 370-400.

(2004). “International Reserves Holdings with Sovereign Risk and Costly Tax Collection,” Economic Journal, vol. 114, (July), pp. 569-91

Aizenman, J., Y. Lee, and Y. Rhee (2004). “International reserves management and capital mobility in a volatile world: Policy considerations and a case study of Korea,” NBER Working paper \# 10534.

Ben-Bassat A. and D. Gottlieb (1992). 'Optimal international reserves and sovereign risk,' Journal of International Economics, vol. 33, pp. 345-362.

Bryant, R. (1980), “A Model of Reserves, Bank Runs, and Deposit Insurance,” Journal of Banking and Finance 4, pp.335-344.

Calvo, G. (1998), “Capital Flows and Capital-Market Crises: The Simple Economics of Sudden Stops,” Journal of Applied Economics, November 1998. and E. Mendoza. (2000) “Contagion, Globalization, and the Volatility of Capital Flows,” in Sebastian Edwards (editor) Capital Flows and the Emerging Economies, Chicago, University Chicago Press, 2000.

Diamond, D. and P. Dybvig (1983). “Bank Runs, Liquidity and Deposit Insurance,” Journal of Political Economy 91, pp. 401-419.

Dooley, M., D. Folkerts-Landau and P. Garber. (2003), “An Essay on the Revived Bretton Woods System,” NBER Working paper \# 9971.

Edison, H. (2003), “Are Foreign Exchange Reserves in Asia Too High?’’ in IMF World Economic Outlook September 2003.

Edwards, S. (1983). “The Demand for International Reserves and Exchange Rate Adjustments: The Case of LDCs, 1964-1972,” Economica, vol. 50, pp. 269-280.

(2004). "Thirty Years of Current Account Imbalances, Current Account Reversals, and Sudden Stops", IMF Staff Papers, Vol. 51, Special Issue. (2005). "Capital Controls, Sudden Stops and Current Account Reversals ", NBER Working Paper \# 11170. 
Flood, R. and P. N. Marion (2001). 'Holding International Reserves in an Era of High Capital Mobility,' in Collins S. M. and Rodrik D., Editors, Brookings Trade Forum 2001, Washington, D.C. : Brookings Institution Press, 2002.

García P. S. and C. G. Soto (2004), “Large Hoarding of International Reserves: Are they worth it?,” manuscript, Chilean Central Bank.

Hutchison M. and I. Noy (2002). "How Bad Are Twins? Output Costs of Currency and Banking Crises,” forthcoming, Journal of Money, Credit and Banking.

Kaminsky, G. and C. Reinhart (1999). "The Twin Crises. The Causes of Banking and Balanceof-Payments Problems,” American Economic Review, 89, June, pp. 473-500.

Kravis, I.B. (1984). “Comparative Studies of National Incomes and Prices,” Journal of Economic Literature, 22, March, pp. 1-39.

Lee, J. (2004). "Insurance Value of International Reserves," IMF Working Paper 04/175.

Prasad, E. and S-J Wei (2005). “The Chinese approach to capital inflows: patterns and possible explanations,” IMF Working Paper 05/79.

Prisman, E. , M. Solvin and M. Sushka (1986). “A general model of the banking firm under conditions of monopoly, uncertainty and recourse,” Journal of Monetary Economics 17 (2): 293-304.

Samuelson, P.A. (1994). “Facets of Balassa-Samuelson Thirty Years Later,” Review of International Economics 2 (3): 201-226. 


\section{DATA Appendix: Definitions of the regression variables}

Reserves: international reserves holdings minus gold, measured in U.S. dollars.

$\mathrm{R}$ to $\mathrm{M}$ : ratio of reserves to the dollar value of broad money.

$\mathrm{R}$ to $\mathrm{Y}$ : ratio of reserves to the dollar value of nominal GDP.

LPOP: $\log$ of population

LYPC: log of per-capita income

LIMY: log of percent import share

MVGX: three-year moving average of the growth rate of real exports (log change), lagged two years in the regression.

VOL_XC: exchange rate volatility, calculated from the monthly exchange rate against the U.S. dollar.

PLDE: the residuals from the regression of national price levels (measured in U.S. dollars) on the per-worker income relative to the U.S. (Table 1A) Time dummies for each year were used to control for time-specific common factors including the unit of denomination.)

CRMEXEM: dummy variable for the period after the Mexico crisis, applied to developing and emerging market countries.

CRASIAEM: dummy variable for the period after the Asian crisis, applied to developing and emerging market countries.

CRMEXEMLA: dummy variable CRMEXEM, applied only to Latin America

CRMEXEMAS: dummy variable CRMEXEM, applied only to Asia

CRASIAEMLA: dummy variable CRASIAEM, applied only to Latin America

CRASIAEMAS: dummy variable CRASIAEM, applied only to Asia

Regressions of Table 1 and Table 2 all include country-specific constant terms. The sample comprises 53 countries that include advanced and emerging-market economies as well as several major developing economies. They are Australia, Austria, Belgium, Canada, Cyprus, Denmark, Finland, France, Germany, Greece, Iceland, Ireland, Italy, Japan, Luxembourg, Netherlands, New Zealand, Norway, Portugal, Spain, Sweden, Switzerland, United Kingdom, United States, Hong Kong SAR, Israel, Korea, Singapore, Taiwan Province of China, Argentina, Brazil, Chile, Colombia, Czech Republic, Hungary, Indonesia, Malaysia, Mexico, Pakistan, Peru, Philippines, Poland, Russia, South Africa, Thailand, Turkey, Venezuela, Algeria, China, Croatia, Egypt, India, and Morocco. Owing to data availability, Greece is excluded from the regressions for Table 1, and Luxembourg, Egypt, and Taiwn Province of China are excluded from the regressions that include price level data. 
Table 1. Reserves to Broad Money

(1980-2000)

\begin{tabular}{|c|c|c|c|c|c|}
\hline & $\mathrm{I}$ & II & III & IV & $\mathrm{V}$ \\
\hline LPOP & $\begin{array}{l}0.281 * * * \\
(0.035)\end{array}$ & $\begin{array}{l}0.183 * * * \\
(0.038)\end{array}$ & $\begin{array}{r}0.022 \\
(0.044)\end{array}$ & $\begin{array}{l}0.137 * * * \\
(0.043)\end{array}$ & $\begin{array}{r}0.021 \\
(0.044)\end{array}$ \\
\hline LYPC & $\begin{array}{l}-0.103 * * * \\
(0.017)\end{array}$ & $\begin{array}{l}-0.090 * * * \\
(0.019)\end{array}$ & $\begin{array}{l}-0.090 * * * \\
(0.018)\end{array}$ & $\begin{array}{l}-0.084 * * * \\
(0.019)\end{array}$ & $\begin{array}{l}-0.092 * * * \\
(0.019)\end{array}$ \\
\hline LIMY & $\begin{array}{l}0.128 * * * \\
(0.015)\end{array}$ & $\begin{array}{l}0.144 * * * \\
(0.017)\end{array}$ & $\begin{array}{l}0.105 * * * \\
(0.017)\end{array}$ & $\begin{array}{l}0.135 * * * \\
(0.017)\end{array}$ & $\begin{array}{l}0.105 \text { *** } \\
(0.017)\end{array}$ \\
\hline VOL_XC & $\begin{array}{l}-0.005 * * * \\
(0.001)\end{array}$ & $\begin{array}{l}-0.004 * * * \\
(0.001)\end{array}$ & $\begin{array}{l}-0.004 * * * \\
(0.001)\end{array}$ & $\begin{array}{l}-0.004 * * * \\
(0.001)\end{array}$ & $\begin{array}{l}-0.004 \text { *** } \\
(0.001)\end{array}$ \\
\hline MVGX & & $\begin{array}{l}0.169 * * \\
(0.059)\end{array}$ & $\begin{array}{l}0.159 * * \\
(0.058)\end{array}$ & $\begin{array}{l}0.197 * * * \\
(0.059)\end{array}$ & $\begin{array}{l}0.169 * * * \\
(0.059)\end{array}$ \\
\hline PLDE & & $\begin{array}{l}0.060 * * * \\
(0.015)\end{array}$ & $\begin{array}{l}0.042 \text { ** } \\
(0.015)\end{array}$ & $\begin{array}{l}0.059 * * * \\
(0.015)\end{array}$ & $\begin{array}{l}0.046 \text { *** } \\
(0.015)\end{array}$ \\
\hline CRMEXEM & & & $\begin{array}{l}0.064 * * * \\
(0.012)\end{array}$ & & $\begin{array}{l}0.063 \text { *** } \\
(0.012)\end{array}$ \\
\hline CRASIAEM & & & $\begin{array}{l}0.027 * * \\
(0.012)\end{array}$ & & $\begin{array}{l}0.022 * \\
(0.013)\end{array}$ \\
\hline CRMEXEMAS & & & & $\begin{array}{c}-0.027 \\
(0.020)\end{array}$ & \\
\hline CRMEXEMLA & & & & $\begin{array}{l}0.065 * * * \\
(0.020)\end{array}$ & \\
\hline CRASIAEMAS & & & & $\begin{array}{l}0.079 * * * \\
(0.024)\end{array}$ & \\
\hline CRASIAEMLA & & & & $\begin{array}{l}-0.055 * * \\
(0.024)\end{array}$ & \\
\hline \multicolumn{2}{|c|}{ MVGX*CRASIAEMAS } & & & & $\begin{array}{r}-0.105 \\
(0.302)\end{array}$ \\
\hline \multicolumn{2}{|c|}{ PLDE*CRASIAEMAS } & & & & $\begin{array}{r}-0.056 \\
(0.057)\end{array}$ \\
\hline R squared & 0.774 & 0.783 & 0.795 & 0.788 & 0.795 \\
\hline Cross-section & 52 & 49 & 49 & 49 & 49 \\
\hline
\end{tabular}

Statistically significant at 1 percent $\left({ }^{* * *}\right), 5$ percent $(* *)$, and 10 percent $(*)$. All regressions included country fixed effects. 
Table 1A. Auxiliary Regressions

Dependent Variable:

National Price Level

Variable

Coefficient

Constant

$4.395 * * *$

(0.015)

Relative GDP per worker

$0.324 * * *$

(0.008)

R-squared

0.439

Sample period

1980 to 2000

Cross section observations

149

Time dummies were included.

Statiscally significant at 1 percent $(* * *)$

Dependent Variable:

Log Change in the Nominal Effective Exchange Rate

Variable

Coefficient

PLDE(-1)

$$
0.346 * * *
$$

PLDE(-2)

$-0.135$

(0.097)

R-squared

0.392994

Sample period

1980 to 2000

Cross section observations

50

Country fixed effects were included.

PLDE refers to the residuals from the price-level regression 
Table 2. Reserves to GDP

(1980-2000)

\begin{tabular}{|c|c|c|c|c|c|}
\hline & I & II & III & IV & V \\
\hline LPOP & $\begin{array}{l}0.232 \text { *** } \\
(0.016)\end{array}$ & $\begin{array}{l}0.181 \text { *** } \\
(0.016)\end{array}$ & $\begin{array}{l}0.099 \text { *** } \\
(0.019)\end{array}$ & $\begin{array}{l}0.169 \text { *** } \\
(0.018)\end{array}$ & $\begin{array}{l}0.095^{* * *} \\
(0.019)\end{array}$ \\
\hline LIMY & $\begin{array}{l}0.045 * * * \\
(0.008)\end{array}$ & $\begin{array}{l}0.056 \text { *** } \\
(0.008)\end{array}$ & $\begin{array}{l}0.036 \text { *** } \\
(0.008)\end{array}$ & $\begin{array}{l}0.051 \text { *** } \\
(0.008)\end{array}$ & $\begin{array}{l}0.034^{* * *} \\
(0.008)\end{array}$ \\
\hline VOL_XC & $\begin{array}{l}-0.001 * * \\
(0.000)\end{array}$ & $\begin{array}{r}0.000 \\
(0.000)\end{array}$ & $\begin{array}{r}0.000 \\
(0.000)\end{array}$ & $\begin{array}{l}-0.001 \text { * } \\
(0.000)\end{array}$ & $\begin{array}{l}-0.001 * \\
(0.000)\end{array}$ \\
\hline MVGX & & $\begin{array}{r}-0.005 \\
(0.028)\end{array}$ & $\begin{array}{l}-0.010 \\
(0.027)\end{array}$ & $\begin{array}{r}0.024 \\
(0.028)\end{array}$ & $\begin{array}{l}-0.011 \\
(0.027)\end{array}$ \\
\hline PLDE & & $\begin{array}{l}0.024 \text { *** } \\
(0.007)\end{array}$ & $\begin{array}{l}0.016 \text { ** } \\
(0.007)\end{array}$ & $\begin{array}{l}0.033 \text { *** } \\
(0.007)\end{array}$ & $\begin{array}{l}0.020 \text { ** } \\
(0.007)\end{array}$ \\
\hline CRMEXEM & & & $\begin{array}{l}0.022 \text { *** } \\
(0.006)\end{array}$ & & $\begin{array}{l}0.022 \text { *** } \\
(0.006)\end{array}$ \\
\hline CRASIAEM & & & $\begin{array}{l}0.031 \text { *** } \\
(0.006)\end{array}$ & & $\begin{array}{l}0.025^{* * *} \\
(0.006)\end{array}$ \\
\hline CRMEXEMAS & & & & $\begin{array}{r}-0.004 \\
(0.010)\end{array}$ & \\
\hline CRMEXEMLA & & & & $\begin{array}{r}-0.011 \\
(0.009)\end{array}$ & \\
\hline CRASIAEMAS & & & & $\begin{array}{l}0.054 \text { *** } \\
(0.011)\end{array}$ & \\
\hline CRASIAEMLA & & & & $\begin{array}{r}-0.016 \\
(0.011)\end{array}$ & \\
\hline \multicolumn{2}{|c|}{ MVGX*CRASIAEMAS } & & & & $\begin{array}{r}0.222 \\
(0.141)\end{array}$ \\
\hline \multicolumn{2}{|c|}{ PLDE*CRASIAEMAS } & & & & $\begin{array}{l}-0.026 \\
(0.026)\end{array}$ \\
\hline R squared & 0.880 & 0.896 & 0.903 & 0.894 & 0.904 \\
\hline Cross-section & 53 & 50 & 50 & 50 & 50 \\
\hline
\end{tabular}

Statistically significant at 1 percent $\left({ }^{* * *}\right), 5$ percent $(* *)$, and 10 percent $(*)$. All regressions included country fixed effects. 
Table 3. Reserves to Broad Money, with capital account liberalizations (1980-2000)

\begin{tabular}{|c|c|c|c|c|c|}
\hline & I & II & III & IV & $\mathrm{V}$ \\
\hline LPOP & $\begin{array}{l}0.172 * * * \\
(0.036)\end{array}$ & $\begin{array}{l}0.100 * * \\
(0.039)\end{array}$ & $\begin{array}{r}-0.050 \\
(0.045)\end{array}$ & $\begin{array}{r}0.028 \\
(0.043)\end{array}$ & $\begin{array}{c}-0.047 \\
(0.045)\end{array}$ \\
\hline LYPC & $\begin{array}{l}-0.105 * * * \\
(0.018)\end{array}$ & $\begin{array}{l}-0.091 * * * \\
(0.019)\end{array}$ & $\begin{array}{l}-0.093 * * * \\
(0.018)\end{array}$ & $\begin{array}{l}-0.103 * * * \\
(0.019)\end{array}$ & $\begin{array}{l}-0.097 * * * \\
(0.018)\end{array}$ \\
\hline LIMY & $\begin{array}{l}0.108 * * * \\
(0.015)\end{array}$ & $\begin{array}{l}0.108 * * * \\
(0.017)\end{array}$ & $\begin{array}{l}0.074 * * * \\
(0.017)\end{array}$ & $\begin{array}{l}0.092 * * * \\
(0.017)\end{array}$ & $\begin{array}{l}0.074^{* * *} \\
(0.017)\end{array}$ \\
\hline VOL_XC & $\begin{array}{l}-0.004 * * * \\
(0.001)\end{array}$ & $\begin{array}{l}-0.004 * * * \\
(0.001)\end{array}$ & $\begin{array}{l}-0.003 * * * \\
(0.001)\end{array}$ & $\begin{array}{l}-0.004 * * * \\
(0.001)\end{array}$ & $\begin{array}{l}-0.004 * * * \\
(0.001)\end{array}$ \\
\hline MVGX & & $\begin{array}{l}0.130 * * \\
(0.060)\end{array}$ & $\begin{array}{l}0.132 * * \\
(0.059)\end{array}$ & $\begin{array}{l}0.176 \text { *** } \\
(0.060)\end{array}$ & $\begin{array}{l}0.123 * * \\
(0.059)\end{array}$ \\
\hline PLDE & & $\begin{array}{r}0.010 \\
(0.016)\end{array}$ & $\begin{array}{r}-0.006 \\
(0.016)\end{array}$ & $\begin{array}{r}0.012 \\
(0.017)\end{array}$ & $\begin{array}{r}0.000 \\
(0.017)\end{array}$ \\
\hline K liberalization & $\begin{array}{l}0.163 * * * \\
(0.020)\end{array}$ & $\begin{array}{l}0.161 * * * \\
(0.023)\end{array}$ & $\begin{array}{l}0.162 \text { *** } \\
(0.022)\end{array}$ & $\begin{array}{l}0.165 * * * \\
(0.022)\end{array}$ & $\begin{array}{l}0.161 * * * \\
(0.022)\end{array}$ \\
\hline CRMEXEM & & & $\begin{array}{l}0.062 * * * \\
(0.012)\end{array}$ & & $\begin{array}{l}0.062 \text { *** } \\
(0.012)\end{array}$ \\
\hline CRASIAEM & & & $\begin{array}{r}0.018 \\
(0.013)\end{array}$ & & $\begin{array}{r}0.007 \\
(0.014)\end{array}$ \\
\hline CRMEXEMAS & & & & $\begin{array}{r}0.019 \\
(0.017)\end{array}$ & \\
\hline CRMEXEMLA & & & & $\begin{array}{l}0.067 * * * \\
(0.019)\end{array}$ & \\
\hline CRASIAEMAS & & & & $\begin{array}{l}0.067 * * * \\
(0.020)\end{array}$ & \\
\hline CRASIAEMLA & & & & $\begin{array}{l}-0.055 * * \\
(0.023)\end{array}$ & \\
\hline \multicolumn{2}{|c|}{ MVGX*CRASIAEMAS } & & & & $\begin{array}{c}0.333 * \\
(0.197)\end{array}$ \\
\hline \multicolumn{2}{|c|}{ PLDE*CRASIAEMAS } & & & & $\begin{array}{r}-0.018 \\
(0.040)\end{array}$ \\
\hline R squared & 0.799 & 0.800 & 0.810 & 0.808 & 0.811 \\
\hline Cross-section & 50 & 49 & 49 & 49 & 49 \\
\hline
\end{tabular}

Statistically significant at 1 percent $(* * *), 5$ percent $(* *)$, and 10 percent $\left(^{*}\right)$. All regressions included country fixed effects. 
Table 4. Reserves to GDP, with capital account liberalizations (1980-2000)

\begin{tabular}{|c|c|c|c|c|c|}
\hline & I & II & III & IV & $\mathrm{V}$ \\
\hline LPOP & $\begin{array}{l}0.208 \text { *** } \\
(0.016)\end{array}$ & $\begin{array}{l}0.167 * * * \\
(0.017)\end{array}$ & $\begin{array}{l}0.088 * * * \\
(0.020)\end{array}$ & $\begin{array}{l}0.117 * * * \\
(0.019)\end{array}$ & $\begin{array}{l}0.091 * * * \\
(0.020)\end{array}$ \\
\hline LIMY & $\begin{array}{l}0.043 \text { *** } \\
(0.007)\end{array}$ & $\begin{array}{l}0.046 \text { *** } \\
(0.008)\end{array}$ & $\begin{array}{l}0.028 \text { *** } \\
(0.008)\end{array}$ & $\begin{array}{l}0.032 * * * \\
(0.008)\end{array}$ & $\begin{array}{l}0.027 \text { *** } \\
(0.008)\end{array}$ \\
\hline VOL_XC & $\begin{array}{l}-0.001 * \\
(0.000)\end{array}$ & $\begin{array}{r}0.000 \\
(0.000)\end{array}$ & $\begin{array}{r}0.000 \\
(0.000)\end{array}$ & $\begin{array}{l}-0.001 * \\
(0.000)\end{array}$ & $\begin{array}{r}0.000 \\
(0.000)\end{array}$ \\
\hline MVGX & & $\begin{array}{r}-0.021 \\
(0.029)\end{array}$ & $\begin{array}{r}-0.019 \\
(0.028)\end{array}$ & $\begin{array}{r}0.028 \\
(0.028)\end{array}$ & $\begin{array}{r}-0.038 \\
(0.028)\end{array}$ \\
\hline PLDE & & $\begin{array}{l}0.014 * \\
(0.008)\end{array}$ & $\begin{array}{r}0.006 \\
(0.008)\end{array}$ & $\begin{array}{l}0.023 * * \\
(0.008)\end{array}$ & $\begin{array}{r}0.009 \\
(0.008)\end{array}$ \\
\hline K liberalization & $\begin{array}{l}0.034 \text { *** } \\
(0.010)\end{array}$ & $\begin{array}{l}0.034 * * * \\
(0.011)\end{array}$ & $\begin{array}{l}0.034 * * * \\
(0.011)\end{array}$ & $\begin{array}{l}0.040 * * * \\
(0.010)\end{array}$ & $\begin{array}{l}0.033 * * * \\
(0.010)\end{array}$ \\
\hline CRMEXEM & & & $\begin{array}{l}0.020 * * * \\
(0.006)\end{array}$ & & $\begin{array}{l}0.020 * * * \\
(0.006)\end{array}$ \\
\hline CRASIAEM & & & $\begin{array}{l}0.031 \text { *** } \\
(0.006)\end{array}$ & & $\begin{array}{l}0.019 \text { *** } \\
(0.007)\end{array}$ \\
\hline CRMEXEMAS & & & & $\begin{array}{l}0.017 \text { ** } \\
(0.008)\end{array}$ & \\
\hline CRMEXEMLA & & & & $\begin{array}{r}-0.006 \\
(0.009)\end{array}$ & \\
\hline CRASIAEMAS & & & & $\begin{array}{l}0.067 * * * \\
(0.010)\end{array}$ & \\
\hline CRASIAEMLA & & & & $\begin{array}{r}-0.015 \\
(0.011)\end{array}$ & \\
\hline \multicolumn{2}{|c|}{ MVGX*CRASIAEMAS } & & & & $\begin{array}{l}0.574 \text { *** } \\
(0.093)\end{array}$ \\
\hline \multicolumn{2}{|c|}{ PLDE*CRASIAEMAS } & & & & $\begin{array}{l}0.035 * \\
(0.019)\end{array}$ \\
\hline R squared & 0.901 & 0.898 & 0.905 & 0.910 & 0.909 \\
\hline Cross-section & 51 & 50 & 50 & 50 & 50 \\
\hline
\end{tabular}

Statistically significant at 1 percent $(* * *), 5$ percent $(* *)$, and 10 percent $\left(^{*}\right)$. All regressions included country fixed effects. 
Table 5: Volatility, reserves and expected surplus.

\begin{tabular}{|c|c|c|c|c|c|c|}
\hline$\lambda$ & $\mathrm{z}^{*}=\mathrm{R} / \mathrm{D}$ & $\mathrm{D}$ & $\mathrm{R}$ & $\mathrm{E}[\Pi]$ & $E[\Pi]_{R=0}$ & ${ }^{D_{\mid R}=0}$ \\
\hline 0 & 0 & 0.15 & 0 & 0.35 & 0.35 & 0.15 \\
\hline 0.2 & 0.15 & 0.17 & 0.026 & 0.35 & 0.34 & 0.16 \\
\hline 0.4 & 0.3 & 0.2 & 0.06 & 0.345 & 0.325 & 0.17 \\
\hline 0.6 & 0.46 & 0.26 & 0.12 & 0.34 & 0.3 & 0.18 \\
\hline
\end{tabular}

The simulation values are $\alpha=0.33 ; \quad \theta=0.5 ; \quad \rho=0.2 ; \quad r_{f}=0.02$. 
Figure 1. Reserves to Broad Money
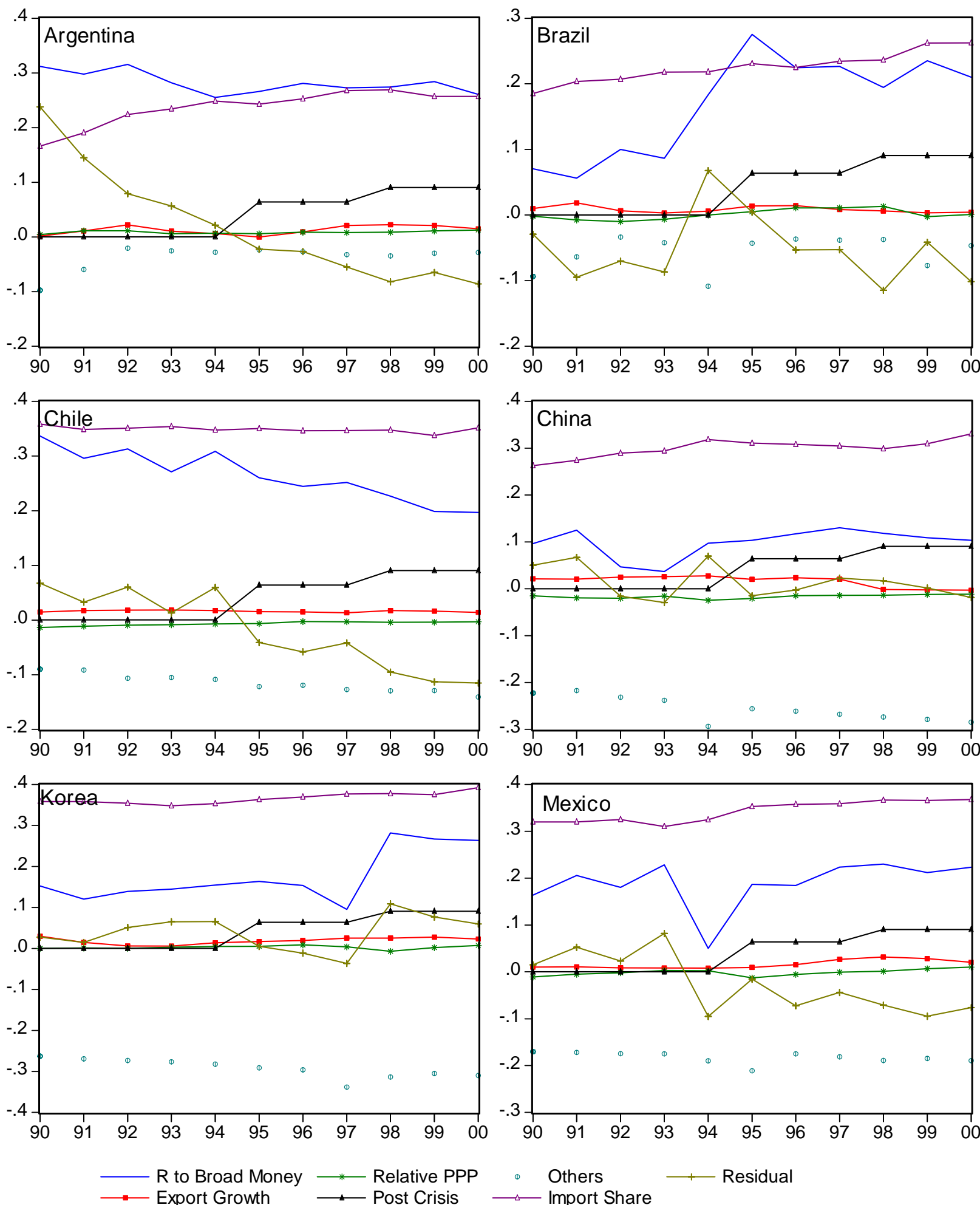

$\stackrel{\text { Others }}{\sim}$ Import Share $\quad$ Residual 
Figure 2. Reserves to GDP
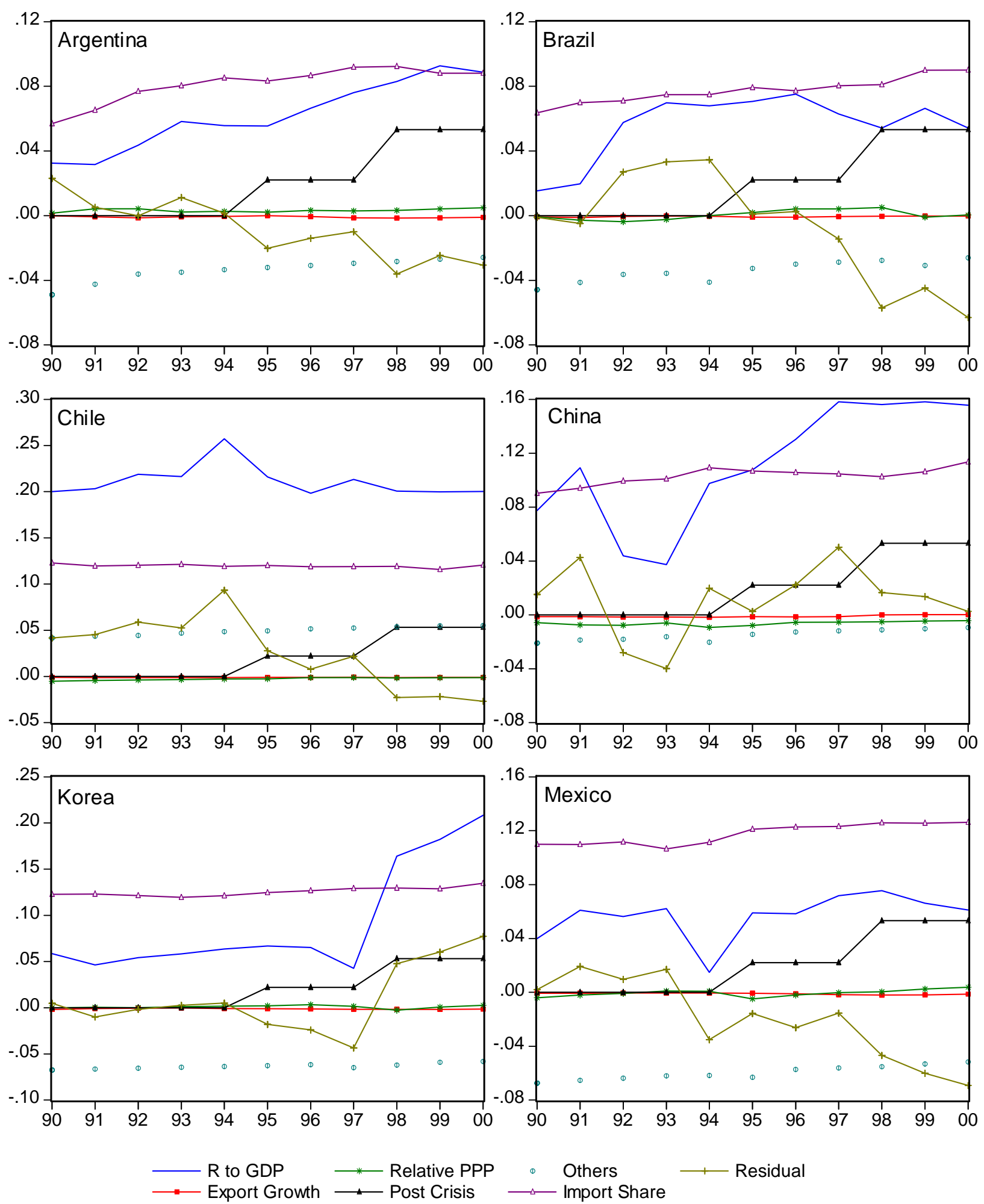
Figure 3. Effects of Selected Variables on the Reserves/GDP Ratio

Effects of a one standard-deviation change in explantory variables

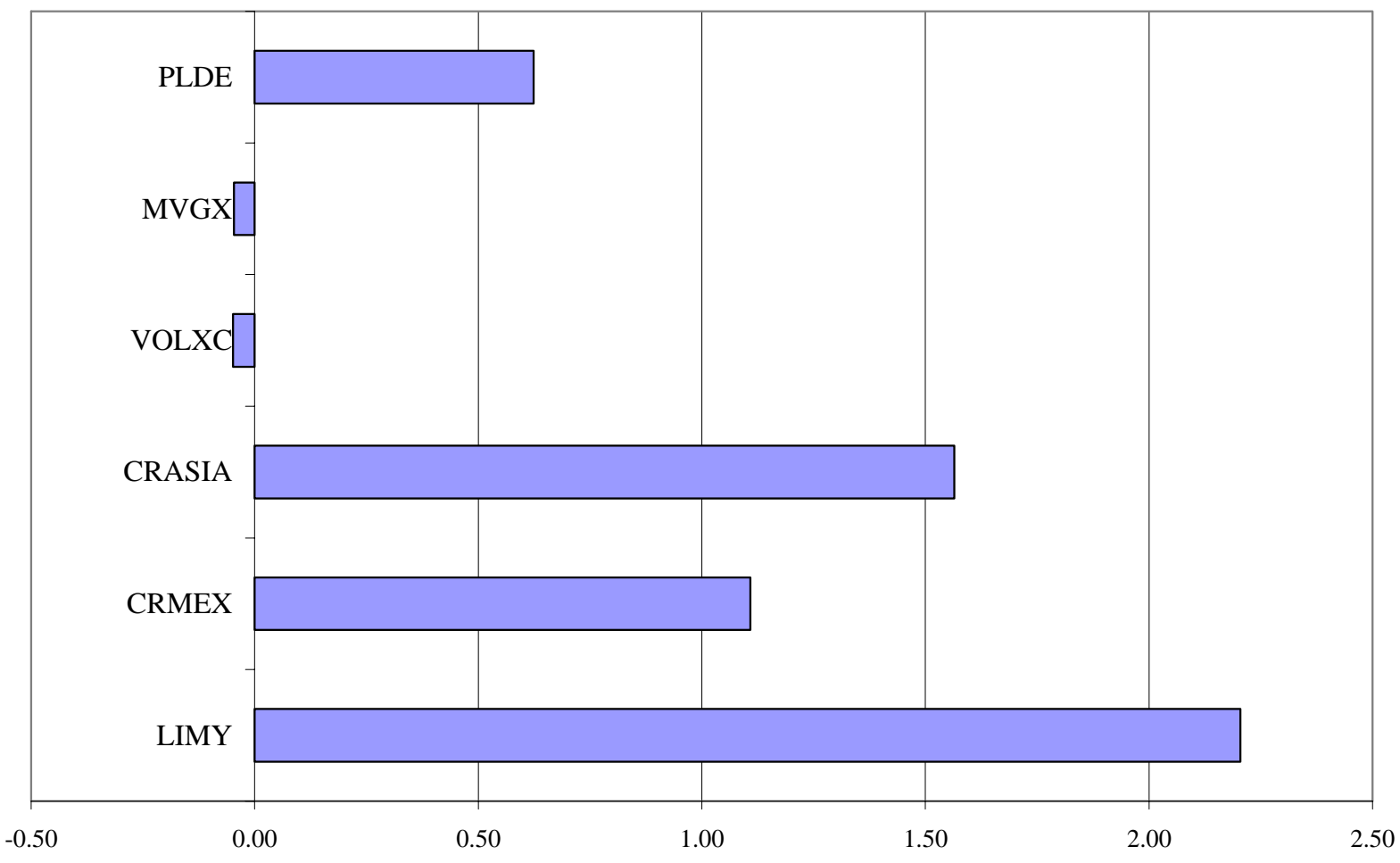


Figure 4. Country specific effects

Reserves to Broad Money

Country specific effects

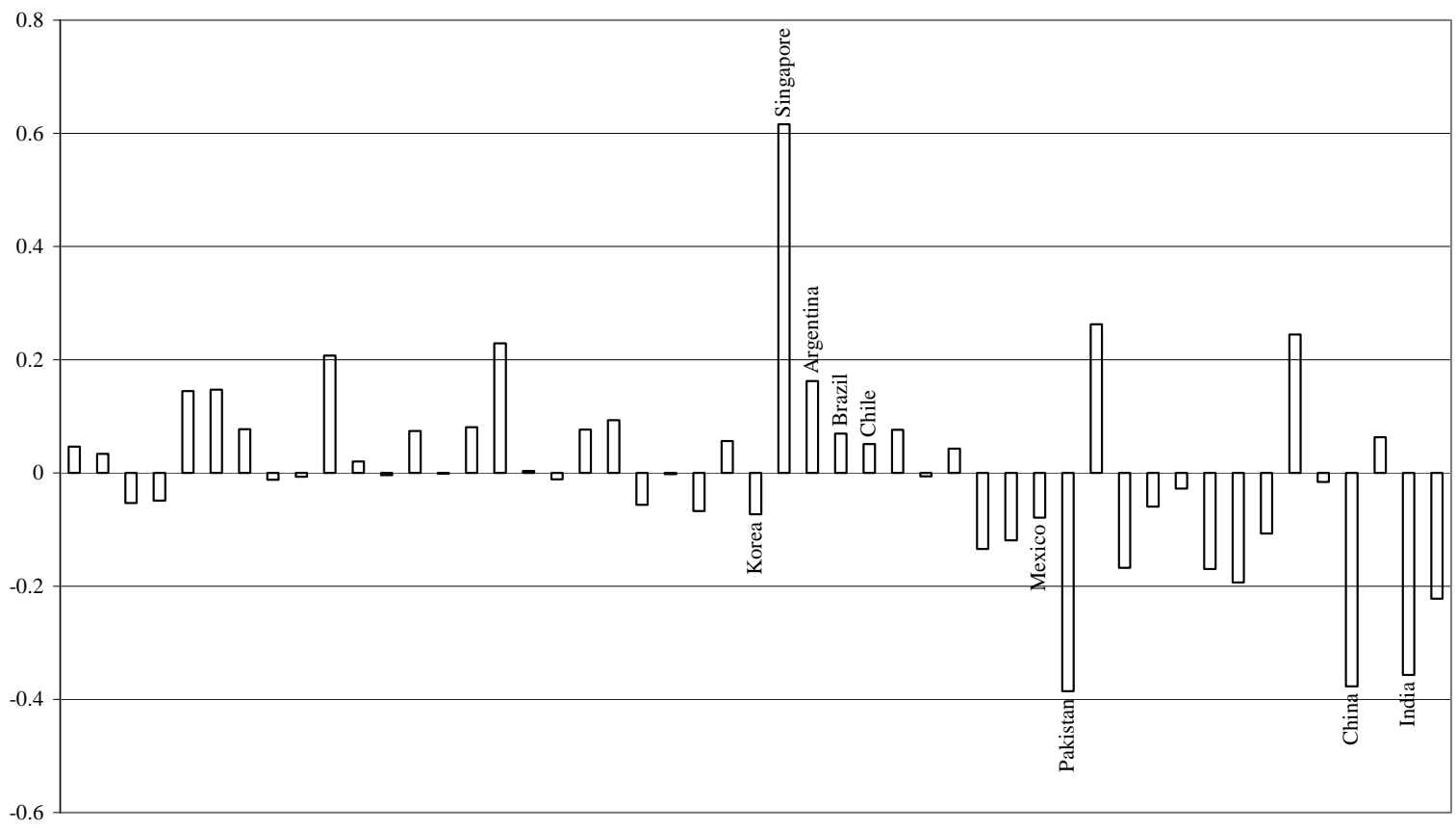

Standard Deviation: 0.21

Reserves to GDP

Country specific effects

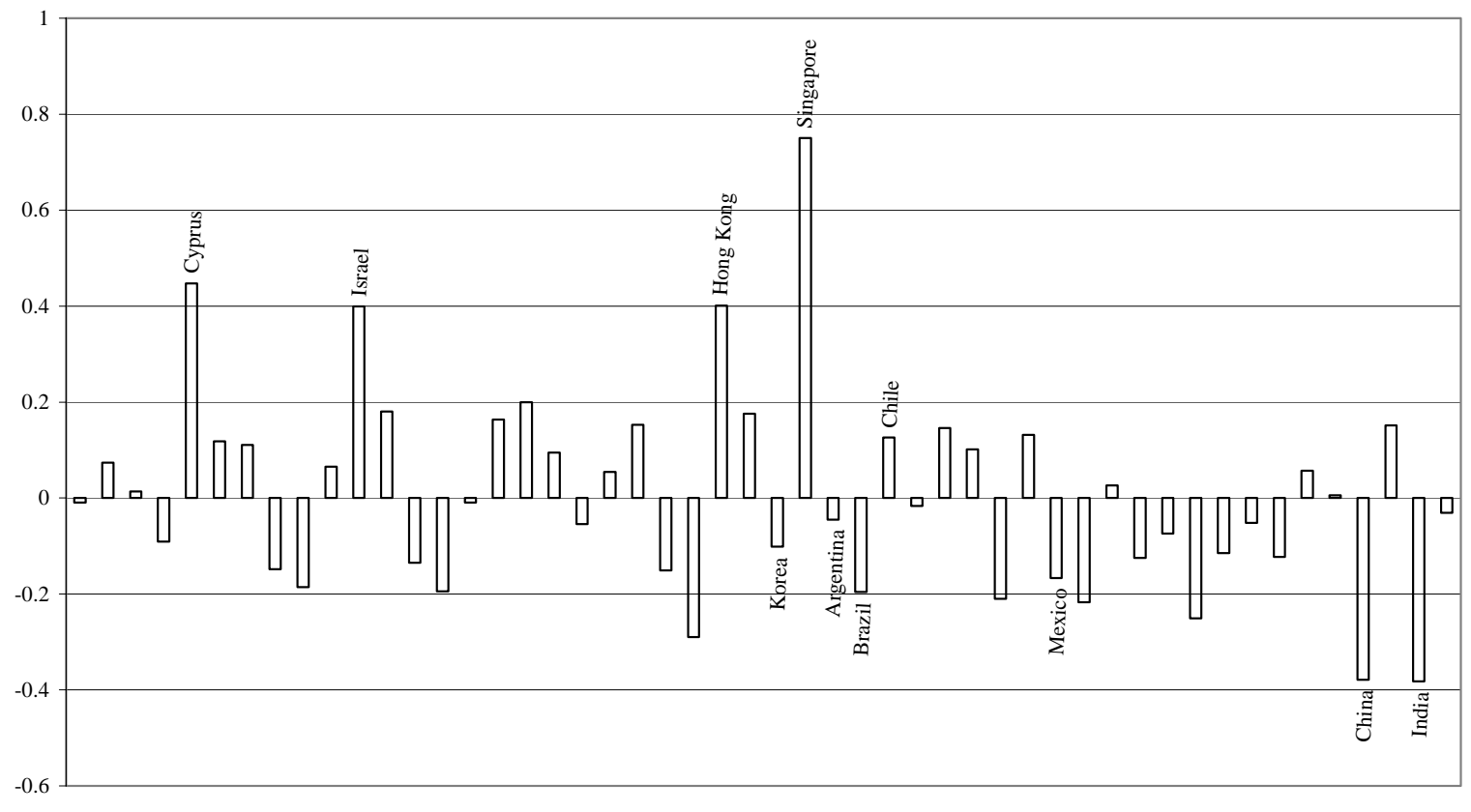

Standard Deviation : 0.17 
Figure 5:

The time line

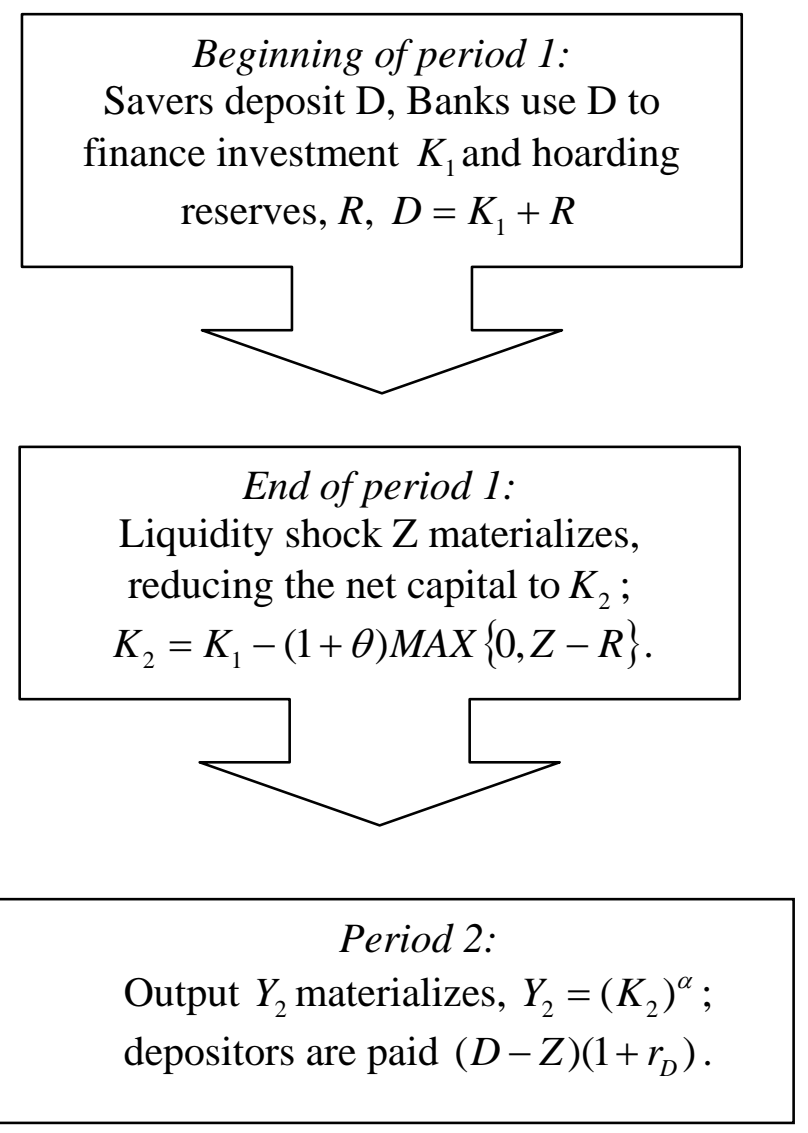




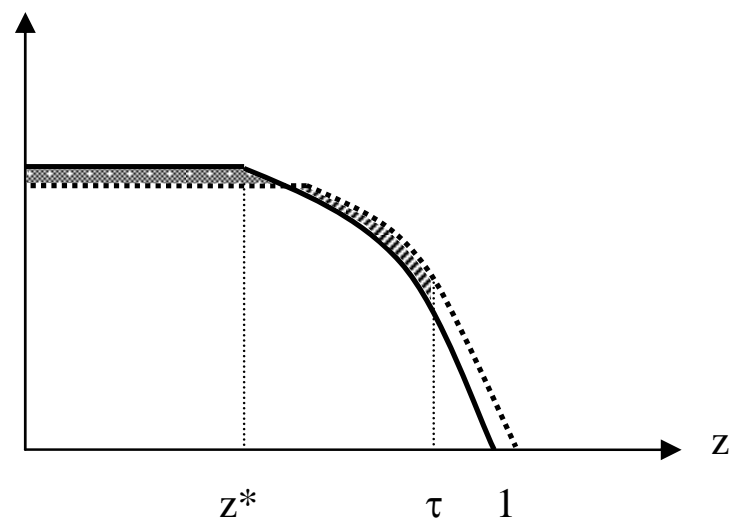

Figure 6

Liquidity shocks, reserves deposit ratio and output

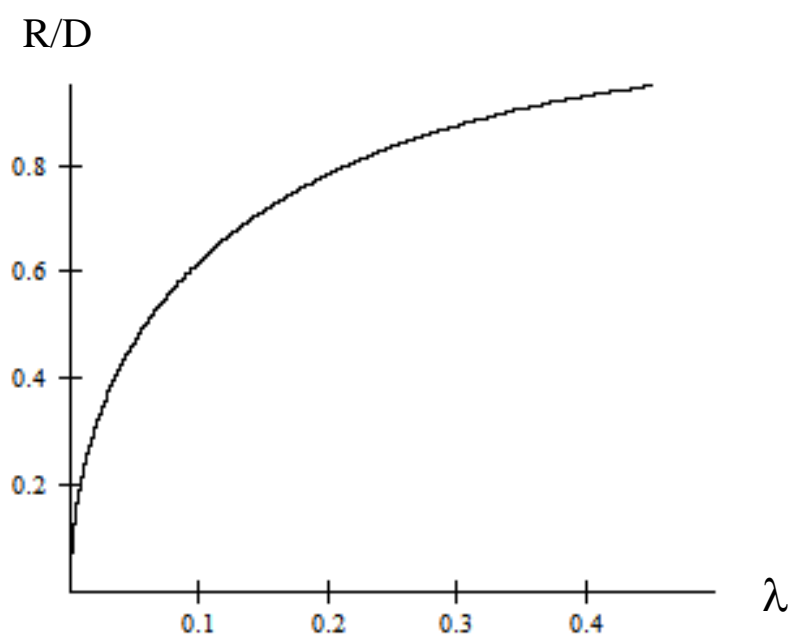

Figure 7

Volatility and $\mathrm{R} / \mathrm{D}$ ratio, constant $\mathrm{D}$.

The simulation values are $\alpha=0.33 ; \quad \theta=0.5 ; \quad \rho=0.2 ; \quad r_{f}=0.02 ; \quad D=D_{0}^{*}=0.15$ 